\begin{tabular}{lr}
\hline D Y N A M I C E C O N O M E T R I C & M O D E L S \\
DOI: http://dx.doi.org/10.12775/DEM.2014.001 & Vol. 14 (2014) 5-28 \\
\hline $\begin{array}{l}\text { Submitted May 5, 2014 } \\
\text { Accepted December 12, } 2014\end{array}$ \\
ISSN \\
\hline
\end{tabular}

\author{
Juliusz Jabłecki , Ryszard Kokoszczyński ${ }^{*}$, \\ Pawel Sakowski, Robert Ślepaczuk*, Piotr Wójcik
}

\title{
Does Historical VIX Term Structure Contain Valuable Information for Predicting VIX Futures?**
}

\begin{abstract}
A b s tract. We suggest that the term structure of VIX futures shows a clear pattern of dependence on the current level of VIX index. At the low levels of VIX (below 20), the term structure is highly upward sloping, while at the high VIX levels (over 30) it is strongly downward sloping. We use these features to predict future VIX futures prices more precisely. We begin by introducing some quantitative measures of volatility term structure (VTS) and volatility risk premium $(V R P)$. We use them further to estimate the distance between the actual value and the fair (model) value of the VTS. We find that this distance has significant predictive power for volatility futures and index futures and we use this feature to design simple strategies to invest in VIX futures.
\end{abstract}

K e y w o r d s: volatility term structure, volatility risk premium, VIX, VIX futures, volatility futures, realized volatility, implied volatility, investment strategies, returns forecasting, efficient risk and return measures

J E L Classification: G11, G14, G15, G23, C61, C22

\footnotetext{
${ }^{*}$ The views presented in this text are those of the authors and do not necessarily represent those of the National Bank of Poland or Union Investment TFI S.A.

Correspondence to: Robert Ślepaczuk, University of Warsaw, Faculty of Economic Sciences, ul. Długa 44/50, 00-241 Warsaw, Poland, tel: +48 225549 174, fax: +48 2283128 46, e-mail: rslepaczuk@wne.uw.edu.pl.

${ }^{* *}$ We gratefully acknowledge government financial support via grant no. UMO-2011/ 03/B/HS4/02298.

(C) 2014 Nicolaus Copernicus University. All rights reserved. http://www.dem.umk.pl/dem
} 


\section{Introduction}

We observe that term structure of VIX futures shows a clear pattern of dependence on the current level of the VIX ${ }^{1}$. Figure 1 shows that the term structure is highly upward sloping when the level of VIX is relatively low (below 20) and it is significantly downward sloping when the level of VIX is high (over 30). We assume that this is mostly due to the market perception of risk in the short and the long-term. That perception reflects strong mean reversion effects and long memory - both visible in volatility time series.

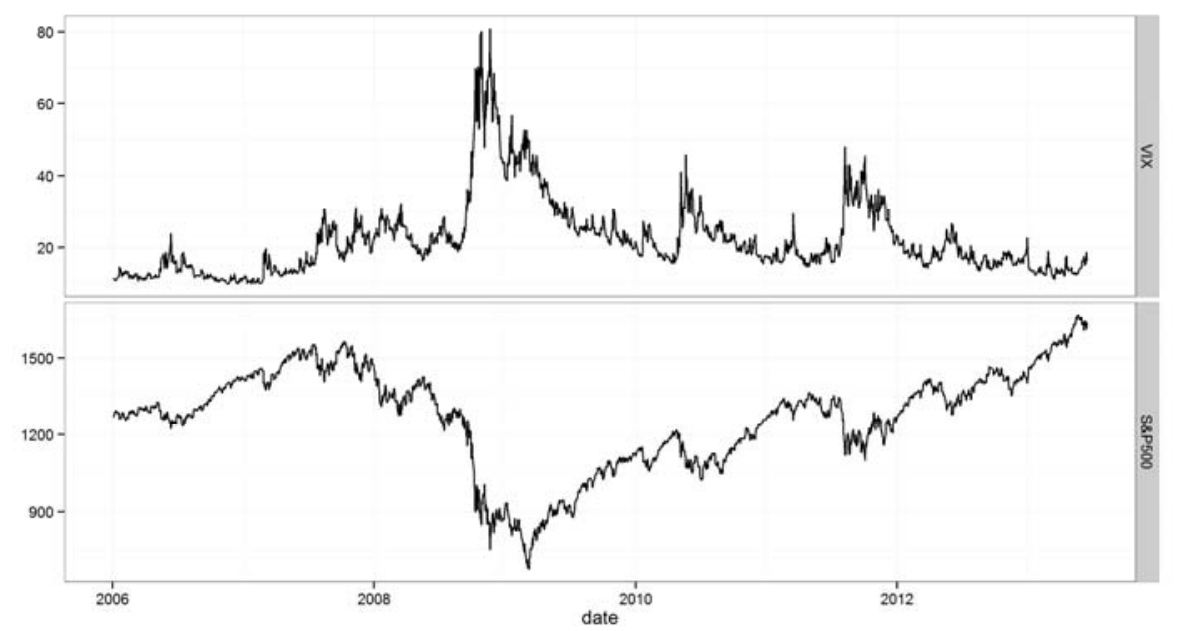

Figure 1. VIX and S\&P500 index quotations from 01/01/2006 until 01/07/2013

In order to investigate the term structure of VIX futures phenomenon more deeply, we introduce two quantitative characteristics of volatility term structure derived directly from the levels of the consecutive VIX futures maturities. These measures are calculated independently for different quintile groups ${ }^{2}$ of VIX and various times to expirations of VIX futures. Further, we use these measures in order to estimate the distance between the actual and the fair (or "theoretical") value of volatility term structure for particular maturity of VIX futures. Subsequently, we include this information in the

\footnotetext{
${ }^{1}$ VIX - volatility index quoted on CBOE, based on implied volatility of S\&P500 index options. It reflects market's expectation of stock market volatility in 30 days horizon. More information could be found in Whaley (1993), CBOE (2003) and CBOE (2009).

${ }^{2}$ As those dependence patterns are not homogenous in the whole sample, we divide our data into VIX levels quintile groups. The rest of the study is conducted consistently on this basis.
} 
process of forecasting VIX levels and VIX futures and we find that this distance has significant predictive power. In the last section, we propose a simple investment strategy that uses VTS in order to predict VIX futures prices.

Volatility research and, in particular, volatility forecasting seems to be one of the most active and successful areas in financial econometrics in recent decades (Andersen et al., 2005). The literature on the VIX and its derivatives is growing very fast, but the number of studies testing the predictability of VIX futures prices is - according to our best knowledge - still very low. Konstantinidi and Skiadopoulos (2011) show only weak evidence of statistically predictable patterns in the evolution of volatility futures prices. They also cannot find a trading strategy with economically significant profits.

Some papers suggest strongly that the use of the information content of the volatility term structure may improve this situation, but the number of studies attempting to examine directly the relationship between the term structure of VIX futures and their future returns or the underlying equity returns is still very limited (Fassas, 2012; Asensio, 2013; Huskaj and Nossman, 2013 and the references therein). In our previous research (Jabłecki et al. 2013a) we found significant relationship between lagged term structure of VIX futures and current level of VIX, yet this didn't translate into better predictions of VIX level.

The paper is thus organized as follows. The next section describes the data. Methodology of this research is presented in the second section. The third section presents the description of simple measures of volatility term structure $(V T S)$. Next section describes the dependence between VIX and S\&P500 index and measures of VTS. Forecasting properties of VTS are presented in the same section. The investment strategies based on these results are presented in the fifth section. The last section concludes and presents possible extensions of this research.

\section{Data Description}

For each trading day we gathered close prices for VIX, VIX futures and S\&P500 index ${ }^{3}$. Initially, the data set included 24 expiration months (from January 2006 until July 2013), but we had to limit their number to 7 because

\footnotetext{
${ }^{3}$ Data are from the following sources:

- VIX - http://cfe.cboe.com/Products/historicalVIX.aspx

- VIX futures - http://cfe.cboe.com/Products/historicalVIX.aspx

- S\&P500 - www.stooq.pl
} 
of liquidity problems for longer maturities. Data preparation for VIX returns also included the process of gap correction in order to omit the problem of very high positive returns at the moment of series change.

Figure 1 and Table 1 present time series for VIX and S\&P500. It is worth noticing that S\&P500 returns are leptokurtic and negatively skewed while VIX returns are also leptokurtic and positively skewed. Additionally, both returns series are negatively correlated.

Table 1. The descriptive statistics for daily returns of VIX and S\&P500 index

\begin{tabular}{ccc}
\hline & VIX returns & S\&P500 returns \\
\hline Number of obs. & 1872 & 1872 \\
Minimum & -0.3505 & -0.0946 \\
Maximum & 0.4960 & 0.1095 \\
1st Quartile & -0.0401 & -0.0049 \\
3rd Quartile & 0.0325 & 0.0061 \\
Mean & 0.0001 & 0.0001 \\
Median & -0.0052 & 0.0008 \\
SE Mean & 0.0016 & 0.0003 \\
LCL Mean & -0.0030 & -0.0005 \\
UCL Mean & 0.0034 & 0.0007 \\
Std. deviation & 0.0719 & 0.0144 \\
Skewness & 0.7022 & -0.2994 \\
Kurtosis & 4.1499 & 8.9920 \\
\hline Correlation & \multicolumn{2}{c}{}
\end{tabular}

Note: All calculations were made on the data from 01/01/2006 until 01/07/2013.

\section{Methodology}

To answer research questions and verify hypotheses we decided to undertake the following steps. As some earlier studies suggest (i.e. Giot, 2005; Simon and Wiggins, 2001), we investigate the relationship we are interested in having classified daily VIX closing prices into five quintile groups ${ }^{4}$. As we observe very low liquidity for longer VIX futures maturities, we withdraw from the sample all futures prices for contracts with expiration longer than seven months ${ }^{5}$. Then, we use OLS to estimate quadratic regressions for closing prices of VIX and VIX futures, independently for each quintile group:

$$
\text { close }_{i}=\beta_{0}+\beta_{1} t_{t m}+\beta_{2} t_{t m}^{2}+\epsilon_{i}
$$

${ }^{4}$ The selection of quintile groups is somewhat arbitrary, nevertheless it was dictated by very heterogeneous shapes of volatility term structure of VTS in different market conditions. It is important to add that it really does not matter if we choose quintile or quartile groups.

${ }^{5}$ This amounted to be less than $25 \%$ of initial sample size. 
where close $_{i}$ - daily closing price of VIX or VIX futures, $\mathrm{ttm}_{i}$ - time to maturity of $i$-th VIX futures $\left(i=1, \ldots, n_{i}\right.$, for VIX $\left.t t m_{i}=0\right), n_{i}-$ size of the $\operatorname{VIX} j$-th quintile group $(j=1, \ldots, 5)$.

As a result, we are able to define the shape of relationship between prices of VIX contracts and their times to expiry. We refer to this relationship as volatility term structure (VTS).

On Figure 2, we draw all observations and shapes of volatility term structure, separately for five VIX quintile groups. It confirms our initial presumption that volatility term structure is dependent on VIX level. It is upward sloping for initial four quintile groups where $\beta_{2}$ parameter is negative. On the other hand, it is downward sloping for the fifth VIX quintile group where $\beta_{2}$ parameter has positive value.

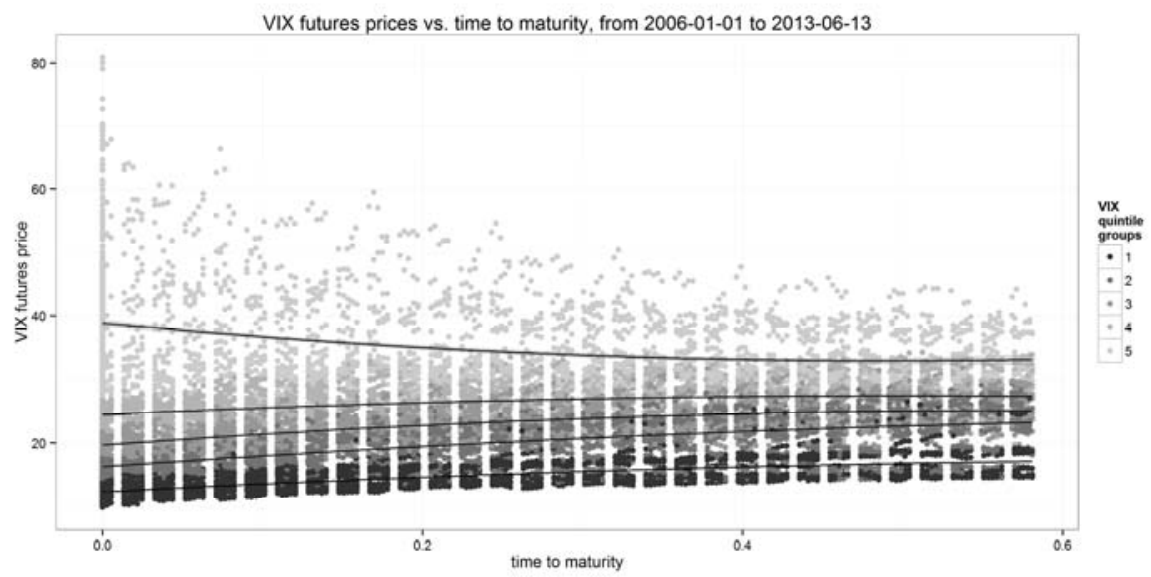

Figure 2. Quadratic regressions for term structure of VIX futures in five different VIX quintile groups. All calculations were made on the data from $01 / 01 / 2006$ until $01 / 07 / 2013$ on the basis of VIX futures with up to 7 months to expiration. VIX futures are quoted on CFE

Based on this initial intuition that volatility term structure is dependent on VIX level and that the slope of VTS depends on the current level of VIX, we propose two different measures of VTS and three different measures of volatility risk premium $(V R P)$ in order to quantify VTS and risk associated with it. We use the results of regression (1) to construct a reference (theoretical) price of volatility futures as a function of the VIX level (quintile) and time to expiration. The distance between the actual price and the reference price allows us to estimate the $V R P$. Then, we show that future returns of VIX and S\&P500 index are dependent on the actual level of VIX and the shape of volatility term structure. This is confirmed with simple regressions 
trying to find some robust patterns which are used later on to construct investment strategy, where the investment algorithms are based on VTS.

\section{Measures of Volatility Term Structure}

We propose two measures of VTS and two measures of VRP. The detailed formulas are presented below. Slope1 is a sum of differences of VIX futures prices with consecutive maturities divided by actual VIX level, calculated separately within each VIX quintile group:

$$
\text { slope } 1_{i}=\frac{F_{j}^{(7)}-F_{j}^{(1)}}{\operatorname{VIX}}
$$

where $F_{j}^{(7)}$-close price of 7-th VIX futures within $j$-th VIX quintile group.

Actual values of Slope1 confirm our observations from the previous section concerning volatility term structure. We see substantial positive differences between last and first contract levels for first four quintile groups and significant negative differences for the last quintile group (Figure 3).

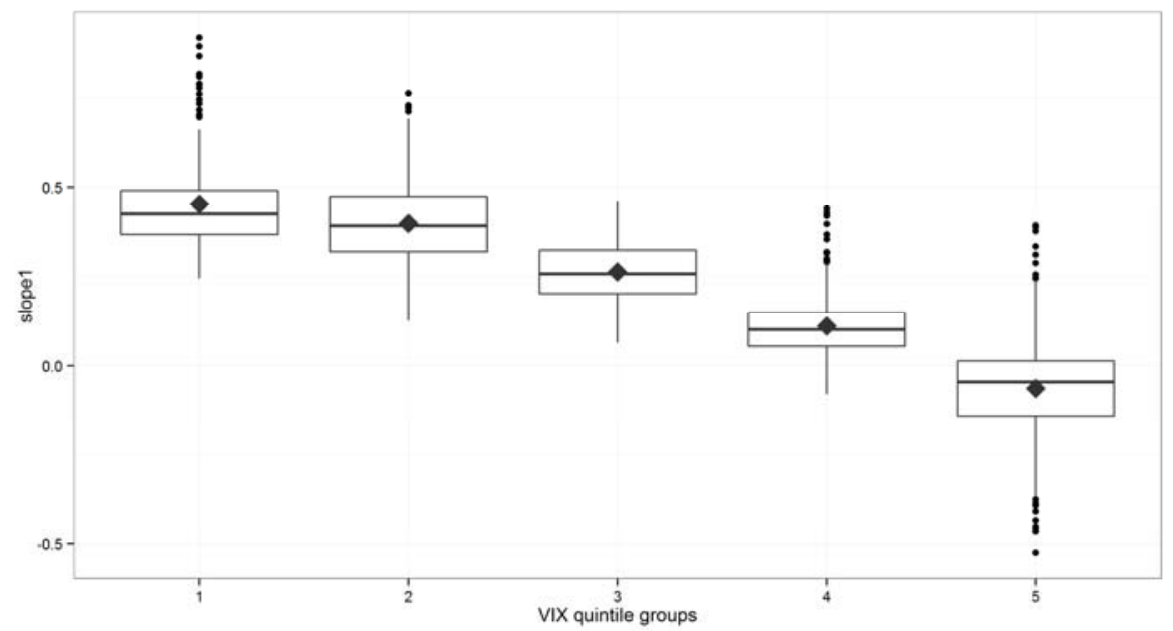

Figure 3. Boxplot for Slope1 with respect to VIX quintile groups. All calculations were made on the data from 01/01/2006 until 01/07/2013 on the basis of VIX futures with up to 7 months to expiration. Diamonds denote group mean values, while black dots denote outliers which are outside $150 \%$ of interquartile range

The second VTS measure, Slope2, is the slope coefficient of the simple linear regression, estimated using OLS separately for every quintile group of VIX levels:

DyNAmic ECONOMETRIC Models 14 (2014) 5-28 


$$
\text { close }_{\mathrm{i}}=\beta_{0}+\beta_{1} \text { ttm }_{\mathrm{i}}+\epsilon_{\mathrm{i}},
$$

where close $_{i}$ - daily closing price of VIX and VIX futures, $t_{t} m_{i}$ - time to maturity of $i$-th VIX futures (for VIX $t t m_{i}=0, i=1, \ldots, n_{i}$ ), $n_{i}$ - size of the VIX $j$-th quintile group $(j=1, \ldots, 5)$.

Slope2 results give support to very similar conclusions as those inferred from Slope1 values (Table 2).

Table 2. The descriptive statistics of Slope2 for VIX quintile groups

\begin{tabular}{|c|c|c|c|c|c|c|c|}
\hline $\begin{array}{l}\text { VIX quintile } \\
\text { group }\end{array}$ & size & $\begin{array}{l}\text { parameters } \\
\text { VIX levels }\end{array}$ & Min & $\operatorname{Max}$ & Avg & Med & SD \\
\hline 1 & 374 & $(0 ; 13.14]$ & 0.9 & 20.3 & 5.7 & 5.4 & 3.1 \\
\hline 2 & 374 & $(13.14 ; 16.03]$ & -5.4 & 20.1 & 9.4 & 10.6 & 5.6 \\
\hline 3 & 375 & $(16.03 ; 19.55]$ & -2.2 & 19.0 & 8.0 & 8.7 & 4.9 \\
\hline 4 & 373 & (19.55:25.41] & -10.5 & 16.1 & 4.3 & 4.6 & 5.1 \\
\hline 5 & 374 & $(25.41 ; 80.86]$ & -71.8 & 8.4 & -9.9 & -5.6 & 13.9 \\
\hline ALL & 1870 & $(0: 80.86]$ & -71.8 & 20.3 & 3.5 & 4.8 & 10.3 \\
\hline
\end{tabular}

Note: All calculations were made on the data from 01/01/2006 until 01/07/2013 on the basis of VIX futures with up to 7 months to expiration.

As the next step we calculate individual volatility risk premium (VRP) by comparing actual VIX futures prices with their ,theoretical” values given by formula (1), for each quintile group separately. $V R P_{j, i}^{(k)}$ is defined as a percentage deviation of $k$-th futures current price from its ,theoretical” price:

$$
V R P_{j, i}^{(k)}=\frac{F_{j, i}^{(k)}-\hat{F}_{j, i}^{(k)}}{\operatorname{VIX}}
$$

where: $j$ - the number of the quintile group $(j \in\{1,2,3,4,5\}), k$ - reference to consecutive VIX futures contracts with ascending time to maturity ( $k \in\{1,2,3,4,5,6,7\}), n_{i}$ - size of the VIX $j$-th quintile group $(j=1, \ldots, 5)$, $F_{j, i}^{(k)}$ - closing price of $k$-th VIX futures contract within $j$-th quintile group, $\hat{F}_{j, i}^{(k)}$ - theoretical value of $k$-th VIX futures index future, calculated from eq. (1), within VIX $j$-th quintile group.

$V R P_{j}^{I}$ shows that inside first four VIX quintile groups we observe on average quite substantial departures from ,theoretical" volatility term structure. They range between $-20 \%$ and $20 \%$. What is more, these deviations are neither skewed towards positive nor negative direction, which means that on average they are equal to zero. The fifth VIX quintile group shows much different picture. Deviations here are much more volatile and they are heavily skewed towards positive values (Figure 4). At the same time, much more 
than half of observations from this group have values below zero (median is on the level of 10\%).

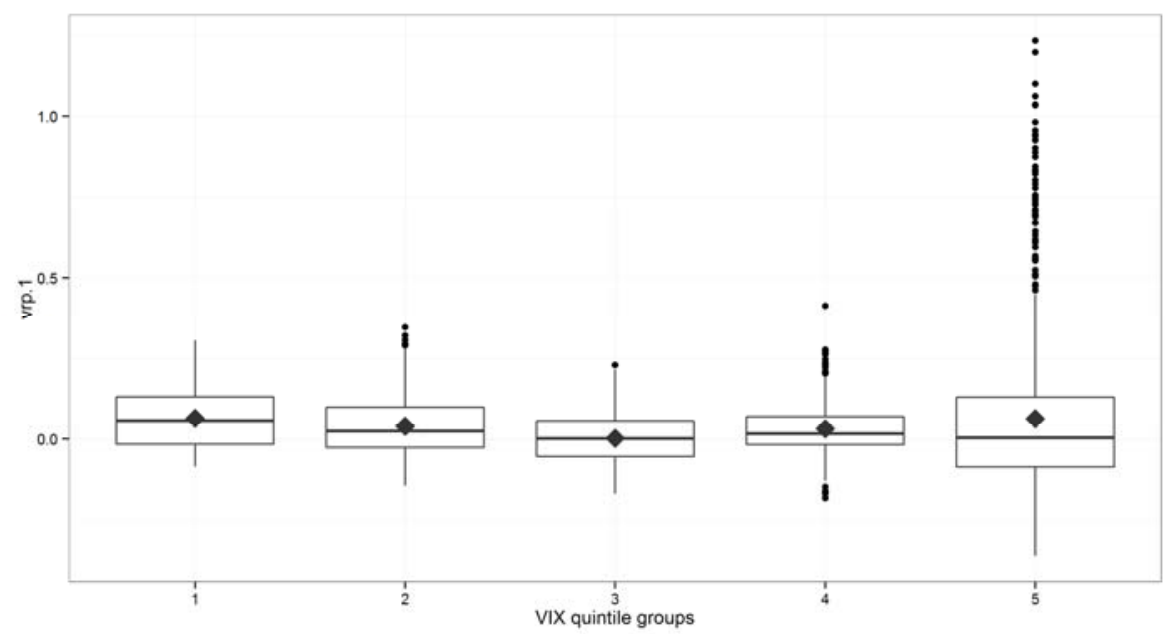

Figure 4. Boxplot for $V R P_{j}^{I}$ with respect to VIX quintile groups. All calculations were made on the data from $01 / 01 / 2006$ until $01 / 07 / 2013$ on the basis of VIX futures with up to 7 months to expiration. Diamonds denote group mean values, while black dots denote outliers which are outside $150 \%$ of interquartile range

In the next step, we estimate the aggregated volatility risk premium for all maturities and for each quintile group. This measure is proposed in two versions in order to correctly present the direction and the magnitude of deviations from the "theoretical" shape:

- aggregated volatility risk premium is the sum of individual volatility risk premiums for all VIX futures maturities, separately for each VIX quintile group:

$$
V R P_{j, i}^{(a g g)}=\sum_{k=1}^{7} V R P_{j, i}^{(k)},
$$

- absolute aggregated volatility risk premium is the sum of absolute individual volatility risk premium for all VIX futures maturities separately for each VIX quintile group:

$$
V R P_{j, i}^{|a g g|}=\sum_{k=1}^{7}\left|V R P_{j, i}^{(k)}\right|,
$$

where: $j$ - the number of the quintile group $(j \in\{1,2,3,4,5\}), k$ - reference to consecutive VIX futures contracts with ascending time to maturity $(k \in\{1,2,3,4,5,6,7\})$. 
$V R P_{j, i}^{(a g g)}$ contains information about the magnitude of departures for all maturities taken together. This could be an important factor for estimating the value of overall shift of VTS. On the other hand, $V R P_{j, i}^{|a g g|}$ contains information about the direction of departures for all maturities together. Similarly, this could helpful to estimate the direction of overall shift of VTS. Figure 5 shows the direction of deviation $\left(V R P_{j, i}^{(a g g)}\right)$, while Figure 6 presents their aggregated values $\left(V R P_{j, i}^{|a g g|}\right)$.

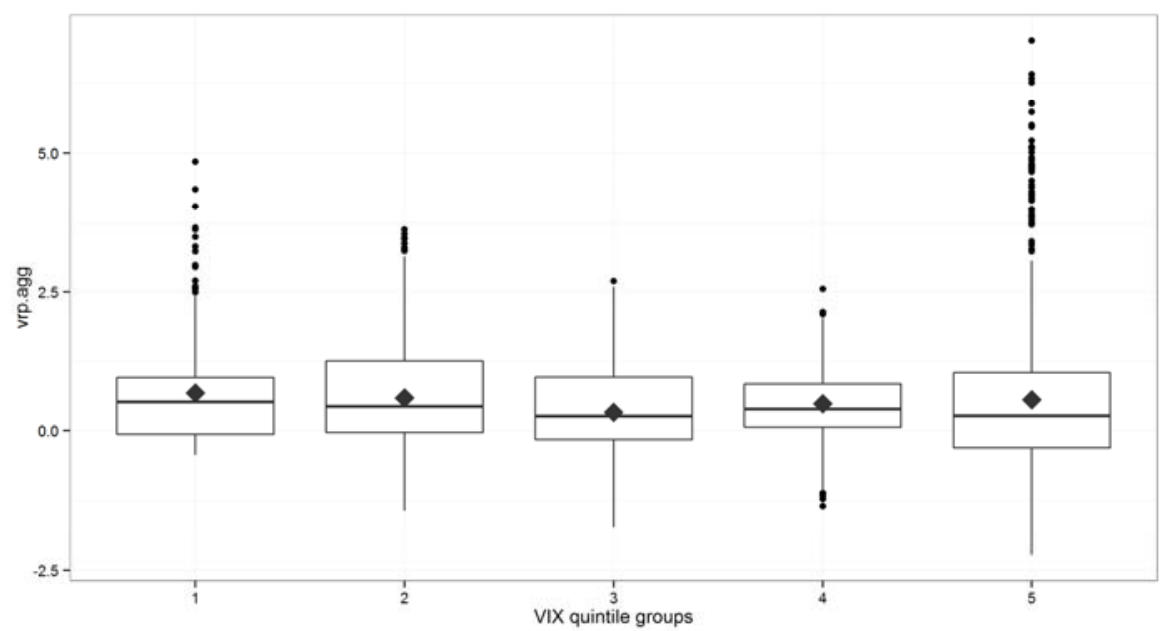

Figure 5. Boxplot for $V R P_{j, i}^{(a g g)}$ with respect to VIX quintile groups. All calculations were made on the data from 01/01/2006 until 01/07/2013 on the basis of VIX futures with up to 7 months to expiration. Diamonds denote group mean values, while black dots denote outliers which are outside $150 \%$ of interquartile range

Figure 5 allows for similar conclusions as Figure 4 but the range of fluctuations inside each quintile group is now much wider - the reason for that being quite trivial because this is the sum of individual volatility risk premiums. Moreover, we observe a large number of outliers inside the first quintile group. They signal quite substantial deviations of the VIX futures from their theoretical shape, most often for maturities from the second one up the result thereof is the highly upward sloping VTS for days with very high values of $V R P_{j, i}^{(a g g)}$ or $V R P_{j, i}^{|a g g|}$. Furthermore, we observe a positive skewness for the fifth VIX quintile group, as is the case for $V R P_{j}^{I}$. 
The situation is quite similar when we analyze Figure 6 . Once again we observe much wider fluctuations in each quintile group than in the case of Figure 4. Moreover, we identify much more outliers in each quintile group than in Figure 5. Observations in each quintile group are more or less positively skewed with the highest skewness in the fifth quintile group. Additionally, median and mean in fifth quintile group are much higher than in other four quintile groups what is partly the result of the highest fluctuations in case of this group on Figure 5.

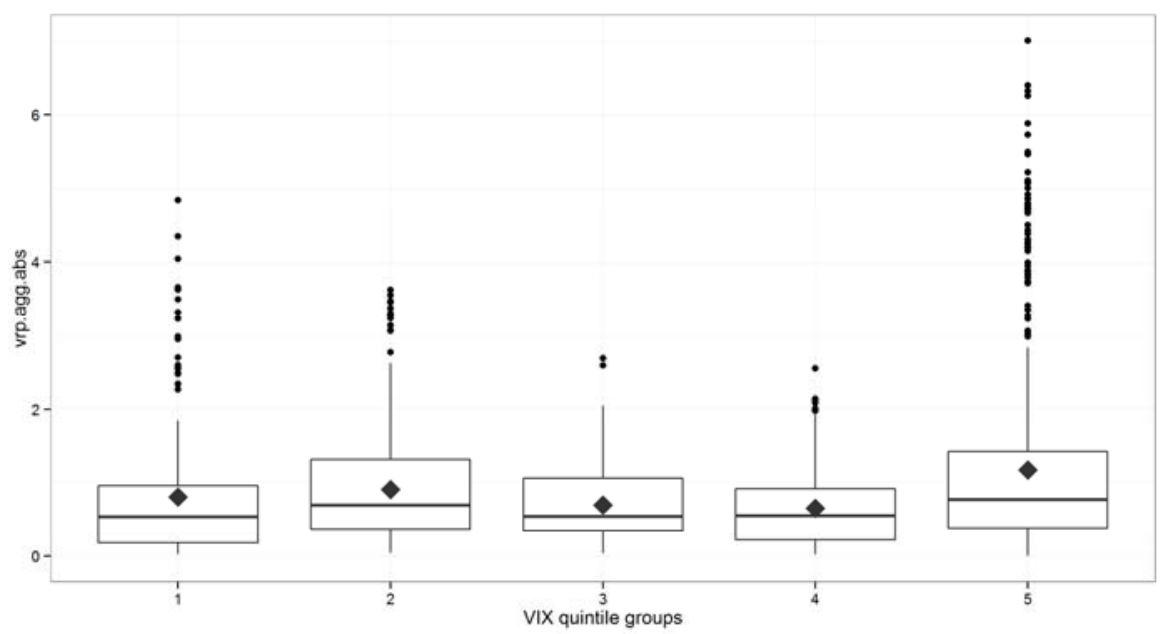

Figure 6. Boxplot for $V R P_{j, i}^{|a g g|}$ with respect to VIX quintile groups. All calculations were made on the data from 01/01/2006 until 01/07/2013 on the basis of VIX futures with up to 7 months to expiration. Diamonds denote group mean values, while black dots denote outliers which are outside $150 \%$ of interquartile range

\section{Forecasting Properties of Volatility Term Structure}

In order to check predictive power of proposed measures of VTS and $V R P$ we present below tables with median 1-month returns of S\&P500 index and VIX conditional on five quintile groups of VIX and:

- five quintile groups for Slope1 (Table 3 and Table 4),

- five quintile groups for Slope2 (Table 5 and Table 6), 
- four quintile groups ${ }^{6}$ for $V R P_{j}^{I}$ (Table 7 and Table 8),

- four quintile groups for $V R P_{j, i}^{(a g g)}$ (Table 9 and Table 10),

- four quintile groups for $\operatorname{VR} P_{j, i}^{|a g g|}$ (Table 11 and Table 12).

Table 3. Median 1-month S\&P500 returns (in \%) conditional on VIX and Slope1 quintile groups

\begin{tabular}{|c|c|c|c|c|c|c|c|}
\hline $\begin{array}{c}\text { VIX } \\
\text { quintile }\end{array}$ & Slope1 & $\begin{array}{c}\text { I } \\
\text { quintile } \\
\text { group }\end{array}$ & $\begin{array}{c}\text { II } \\
\text { quintile } \\
\text { group }\end{array}$ & $\begin{array}{l}\text { III } \\
\text { quintile } \\
\text { group }\end{array}$ & $\begin{array}{c}\text { IV } \\
\text { quintile } \\
\text { group }\end{array}$ & $\begin{array}{c}\mathrm{V} \\
\text { quintile } \\
\text { group }\end{array}$ & ALL \\
\hline group & VIX level & $\begin{array}{r}{[-0.53:} \\
-0.02]\end{array}$ & $\begin{array}{c}(-0.02: \\
0.1]\end{array}$ & $\begin{array}{l}0.1: \\
0.25]\end{array}$ & $\begin{array}{c}0.25: \\
0.39]\end{array}$ & $\begin{array}{l}\text { (0.39: } \\
0.92]\end{array}$ & $\begin{array}{c}{[-0.53:} \\
0.92]\end{array}$ \\
\hline 1 & [9.89:14.18] & NA & 3.03 & 1.22 & 1.74 & 1.14 & 1.27 \\
\hline 2 & (14.18:17.74] & 5.46 & 0.81 & 2.17 & -0.18 & 0.72 & 0.86 \\
\hline 3 & $(17.74: 21.68]$ & 0.31 & -3.13 & 0.11 & 2.34 & 3.14 & 1.19 \\
\hline 4 & (21.68:26.85] & 1.98 & 1.39 & 2.84 & 3.2 & 4.12 & 2.48 \\
\hline 5 & $(26.85: 80.86]$ & 0.52 & 2.94 & 8.00 & NA & NA & 1.23 \\
\hline ALL & [9.89:80.86] & 0.91 & 0.87 & 1.55 & 1.74 & 1.4 & 1.33 \\
\hline
\end{tabular}

Note: All calculations were made on the data from 01/01/2006 until 01/07/2013 on the basis of VIX futures with up to 7 months to expiration.

Table 4. Median 1-month VIX returns (in \%) conditional on VIX and Slope1 quintile groups

\begin{tabular}{|c|c|c|c|c|c|c|c|}
\hline $\begin{array}{c}\text { VIX } \\
\text { quintile }\end{array}$ & Slope1 & $\begin{array}{c}\text { I } \\
\text { quintile } \\
\text { group }\end{array}$ & $\begin{array}{l}\text { II } \\
\text { quintile } \\
\text { group }\end{array}$ & $\begin{array}{l}\text { III } \\
\text { quintile } \\
\text { group }\end{array}$ & $\begin{array}{l}\text { IV } \\
\text { quintile } \\
\text { group }\end{array}$ & $\begin{array}{l}\text { V } \\
\text { quintile } \\
\text { group }\end{array}$ & ALL \\
\hline group & VIX level & $\begin{array}{r}{[-0.53:} \\
-0.02]\end{array}$ & $\begin{array}{c}(-0.02: \\
0.1]\end{array}$ & (0.1: 0.25] & $\begin{array}{l}0.25: \\
0.39]\end{array}$ & $\begin{array}{l}0.39: \\
0.92]\end{array}$ & $\begin{array}{c}{[-0.53:} \\
0.92]\end{array}$ \\
\hline 1 & [9.89:14.18] & NA & -0.04 & 0.91 & 143 & 5.01 & 2.52 \\
\hline 2 & (14.18:17.74] & -27.7 & -2.88 & -8.46 & 9.84 & 6.54 & 5.36 \\
\hline 3 & (17.74:21.68] & 1.27 & 14.95 & -0.92 & -7.27 & -8.53 & -3.39 \\
\hline 4 & (21.68:26.85] & -14.99 & -1.34 & -7.70 & -8.50 & -11.94 & -7.62 \\
\hline 5 & (26.85:80.86] & -1144 & -12.78 & -16.01 & NA & NA & -12.06 \\
\hline ALL & {$[9.89: 80.86]$} & -11.95 & -1.9 & -3.07 & -1.12 & 2.92 & -2.68 \\
\hline
\end{tabular}

Note: All calculations were made on the data from 01/01/2006 until 01/07/2013 on the basis of VIX futures with up to 7 months to expiration. Bold fonts denote values significantly different from zero.

We try further to find with various VTS and VRP measures any patterns of relationship between S\&P500 index and VIX returns. Table 3. shows that we cannot find any clear dependence between S\&P500 return and VIX quintile groups and this observation does not change for all other tables describ-

\footnotetext{
${ }^{6}$ We divide VRP measures into quartile groups because their fluctuations are not homogenous. We choose quartile groups for VRP instead of quintile groups selected for VIX to make results and then definitions of investment strategies more transparent.
} 
ing S\&P500 returns (Table 3, Table 5, Table 7, Table 9, Table 11). Additionally, we can see that S\&P500 returns do not depend on Slope1 levels.

Table 5. Median 1-month S\&P500 returns (in \%) conditional on VIX and Slope2 quintile groups

\begin{tabular}{|c|c|c|c|c|c|c|c|}
\hline $\begin{array}{c}\text { VIX } \\
\text { quintile }\end{array}$ & Slope2 & $\begin{array}{c}\text { I } \\
\text { quintile } \\
\text { group }\end{array}$ & $\begin{array}{c}\text { II } \\
\text { quintile } \\
\text { group }\end{array}$ & $\begin{array}{l}\text { III } \\
\text { quintile } \\
\text { group }\end{array}$ & $\begin{array}{l}\text { IV } \\
\text { quintile } \\
\text { group }\end{array}$ & $\begin{array}{c}\mathrm{V} \\
\text { quintile } \\
\text { group }\end{array}$ & ALL \\
\hline group & VIX level & $\begin{array}{c}{[-71.83:} \\
-0.72]\end{array}$ & $\begin{array}{c}(-0.72: \\
2.87]\end{array}$ & $\begin{array}{l}2.87: \\
6.88]\end{array}$ & $\begin{array}{l}6.88: \\
10.54]\end{array}$ & $\begin{array}{l}10.54: \\
20.36]\end{array}$ & $\begin{array}{c}-71.83: \\
20.36]\end{array}$ \\
\hline 1 & [9.89:14.18] & NA & 1.07 & 1.34 & 1.23 & 2.61 & 1.27 \\
\hline 2 & (14.18:17.74] & 5.46 & 0.81 & 1.76 & 1.67 & 0.07 & 0.86 \\
\hline 3 & (17.74:21.68] & 1.04 & -2.57 & -2.29 & 1.63 & 2.99 & 1.19 \\
\hline 4 & (21.68:26.85] & 1.98 & -2.72 & 2.79 & 3.27 & 3.21 & 2.48 \\
\hline 5 & (26.85:80.86] & 0.59 & 2.88 & 1.97 & 9.10 & NA & 1.23 \\
\hline ALL & {$[9.89: 80.86]$} & 0.98 & 0.55 & 1.44 & 1.75 & 1.83 & 1.33 \\
\hline
\end{tabular}

Note: All calculations were made on the data from 01/01/2006 until 01/07/2013 on the basis of VIX futures with up to 7 months to expiration.

Table 6. Median 1-month VIX returns (in \%) conditional on VIX and Slope2 quintile groups

\begin{tabular}{|c|c|c|c|c|c|c|c|}
\hline $\begin{array}{c}\text { VIX } \\
\text { quintile }\end{array}$ & Slope2 & $\begin{array}{c}\text { I } \\
\text { quintile } \\
\text { group }\end{array}$ & $\begin{array}{l}\text { II } \\
\text { quintile } \\
\text { group }\end{array}$ & $\begin{array}{l}\text { III } \\
\text { quintile } \\
\text { group }\end{array}$ & $\begin{array}{l}\text { IV } \\
\text { quintile } \\
\text { group }\end{array}$ & $\begin{array}{c}\mathrm{V} \\
\text { quintile } \\
\text { group }\end{array}$ & ALL \\
\hline group & VIX level & $\begin{array}{c}{[-71.83:} \\
-0.72]\end{array}$ & $\begin{array}{c}(-0.72: \\
2.87]\end{array}$ & $\begin{array}{l}\text { (2.87: } \\
6.88]\end{array}$ & $\begin{array}{l}\text { (6.88: } \\
10.54]\end{array}$ & $\begin{array}{c}10.54: \\
20.36\end{array}$ & $\begin{array}{c}{[-71.83:} \\
20.36]\end{array}$ \\
\hline 1 & [9.89:14.18] & NA & 8.63 & 0.85 & 3.04 & -0.84 & 2.52 \\
\hline 2 & (14.18:17.74] & -27.7 & -2.88 & -11.78 & 2.53 & 10.79 & 5.36 \\
\hline 3 & (17.74:21.68] & -14.21 & 13.89 & 13.99 & -5.05 & -8.47 & -3.39 \\
\hline 4 & (21.68:26.85] & -14.99 & 0.63 & -3.38 & -11.93 & -8.33 & -7.62 \\
\hline 5 & (26.85:80.86] & -11.91 & -11.24 & -14.69 & -16.10 & NA & -12.06 \\
\hline ALL & [9.89:80.86] & -12.64 & 0.87 & -1.71 & -0.99 & -0.57 & -2.68 \\
\hline
\end{tabular}

Note: All calculations were made on the data from 01/01/2006 until 01/07/2013 on the basis of VIX futures with up to 7 months to expiration. Bold fonts denote values significantly different from zero.

On the other hand, we can observe - in all relevant tables describing VIX returns (Table 4, Table 6, Table 8, Table 10 and Table 12) - that VIX returns decrease almost monotonically, while VIX level moves from the first to the fifth quintile group. At the same table, we can see that VIX returns increase almost monotonically while Slope1 moves from the first to the fifth quintile group. Generally, Table 4 informs us about very high positive VIX returns for the first and the second VIX quintile groups and for the fourth and the fifth Slope1 quintile groups. On the other hand, we observe very high negative VIX returns for the fourth and the fifth VIX quintile groups and for the first and for the second Slopel quintile groups. 
Slope 2 discloses additional information. Table 5 shows that S\&P500 index returns increase monotonically while Slope 2 moves from the first to the fifth quintile group. Table 6, describing the dependence of VIX returns on the Slope2 values, allows for almost the same conclusions as in the case of Table 4. The general conclusion concerning the part of the table with high positive and high negative returns is once again the same as in the case of Table 4.

Table 7. Median 1-month S\&P500 returns (in \%) conditional on VIX quintile groups and $V R P_{j}^{I}$ quartile groups

\begin{tabular}{ccccccc}
\hline \multirow{2}{*}{$\begin{array}{c}\text { VIX } \\
\text { quintile } \\
\text { Group }\end{array}$} & \multirow{2}{*}{$\begin{array}{c}\text { I } \\
\text { quartile }\end{array}$} & $\begin{array}{c}\text { II } \\
\text { quartile } \\
\text { group }\end{array}$ & $\begin{array}{c}\text { III } \\
\text { quartile } \\
\text { group }\end{array}$ & $\begin{array}{c}\text { IV } \\
\text { quartile } \\
\text { group }\end{array}$ & ALL \\
\hline 1 & \multirow{2}{*}{ VIX level } & {$[-0.34:$} & $(-0.08:$ & $(-0.01:$ & $(0.06:$ & {$[-0.34:$} \\
2 & {$[9.89: 14.18]$} & 0.68 & 0.95 & 1.83 & 1.56 & 1.27 \\
3 & $(14.18: 17.74]$ & 1.77 & 0.44 & -1.74 & 2.18 & 0.86 \\
4 & $(17.74: 21.68]$ & 1.84 & 1.19 & 0.19 & 1.78 & 1.19 \\
5 & $(21.68: 26.85]$ & 0.56 & 1.23 & 2.6 & 4.78 & 2.48 \\
\hline ALL & $(26.85: 80.86]$ & 1.08 & 2.99 & 5.68 & -1.60 & 1.23 \\
\hline
\end{tabular}

Note: All calculations were made on the data from 01/01/2006 until 01/07/2013 on the basis of VIX futures with up to 7 months to expiration.

Table 8. Median 1-month VIX returns (in \%) conditional on VIX quintile groups and $V R P_{j}^{I}$ quartile groups

\begin{tabular}{ccccccc}
\hline \multirow{2}{*}{$\begin{array}{c}\text { VIX } \\
\text { quintile } \\
\text { group }\end{array}$} & \multirow{2}{*}{$\begin{array}{c}\mathrm{I} R P_{j}^{I} \\
\end{array}$} & $\begin{array}{c}\text { quartile } \\
\text { group }\end{array}$ & $\begin{array}{c}\text { II } \\
\text { quartile } \\
\text { group }\end{array}$ & $\begin{array}{c}\text { III } \\
\text { quartile } \\
\text { group }\end{array}$ & $\begin{array}{c}\text { IV } \\
\text { quartile } \\
\text { group }\end{array}$ & ALL \\
\cline { 2 - 7 } & \multirow{2}{*}{ VIX level } & {$[-0.34:$} & $(-0.08:$ & $(-0.01:$ & $(0.06:$ & {$[-0.34:$} \\
\hline 1 & {$[9.89: 14.18]$} & 5.74 & 0.26 & $\mathbf{0 . 4 9}$ & $\mathbf{5 . 4 3}$ & 2.52 \\
2 & $(14.18: 17.74]$ & -6.32 & 2.10 & $\mathbf{1 5 . 2 7}$ & $\mathbf{1 6 9}$ & 5.36 \\
3 & $(17.74: 21.68]$ & $\mathbf{- 1 2 . 0 0}$ & 0.31 & 3.52 & -6.55 & -3.39 \\
4 & $(21.68: 26.85]$ & $\mathbf{- 3 . 6 7}$ & $\mathbf{- 8 . 0 1}$ & $\mathbf{- 8 . 5 9}$ & $\mathbf{- 6 . 3 1}$ & $\mathbf{- 7 . 6 2}$ \\
5 & $(26.85: 80.86]$ & $\mathbf{- 1 1 7 9}$ & $\mathbf{- 1 5 . 9}$ & $\mathbf{- 1 6 . 5 5}$ & $\mathbf{- 9 . 7 6}$ & $\mathbf{- 1 2 . 0 6}$ \\
\hline ALL & {$[9.89: 80.86]$} & -5.37 & -2.28 & 0.15 & -3.03 & -2.68 \\
\hline
\end{tabular}

Note: All calculations were made on the data from 01/01/2006 until 01/07/2013 on the basis of VIX futures with up to 7 months to expiration. Bold fonts denote values significantly different from zero.

Table 7 shows that S\&P500 returns increase monotonically with the increase of $V R P_{j}^{I}$ values. On the other hand, we cannot see any clear dependence between VIX returns and $V R P_{j}^{I}$ values (Table 8). Contrary to the 
latter, the general conclusion concerning the part of the table with high positive and high negative returns still holds.

In Table 9 we find the most ideal dependence of S\&P500 returns. They increase monotonically with the increase of $V R P_{j, i}^{(a g g)}$ values. There is no clear dependence between VIX returns and $V R P_{j, i}^{(a g g)}$ values (Table 10). Once again, the general conclusion concerning the part of the table with high positive and high negative returns still holds.

Table 9. Median 1-month S\&P500 returns (in \%) conditional on VIX quintile groups and $V R P_{j, i}^{(a g g)}$ quartile groups

\begin{tabular}{|c|c|c|c|c|c|c|}
\hline $\begin{array}{c}\text { VIX } \\
\text { quintile }\end{array}$ & $V R P_{j . i}^{(a g g)}$ & $\begin{array}{c}\text { I } \\
\text { quartile } \\
\text { group }\end{array}$ & $\begin{array}{c}\text { II } \\
\text { quartile } \\
\text { group }\end{array}$ & $\begin{array}{c}\text { III } \\
\text { quartile } \\
\text { group }\end{array}$ & $\begin{array}{c}\text { IV } \\
\text { quartile } \\
\text { group }\end{array}$ & ALL \\
\hline Group & VIX level & $\begin{array}{l}{[-2.19:} \\
-0.55]\end{array}$ & $\begin{array}{l}(-0.55: \\
-0.11]\end{array}$ & $\begin{array}{c}(-0.11: \\
0.58]\end{array}$ & $\begin{array}{l}\text { (0.58: } \\
\text { 3.68] }\end{array}$ & $\begin{array}{c}{[-2.19:} \\
3.68]\end{array}$ \\
\hline 1 & [9.89:14.18] & 0.77 & 0.82 & 2.11 & 2.02 & 1.27 \\
\hline 2 & (14.18:17.74] & 1.41 & 1.40 & -1.93 & 2.16 & 0.86 \\
\hline 3 & $(17.74: 21.68]$ & 0.28 & -0.40 & -0.17 & 2.75 & 1.19 \\
\hline 4 & (21.68:26.85] & -0.56 & 1.88 & 2.60 & 4.21 & 2.48 \\
\hline 5 & (26.85:80.86] & 0.42 & 2.90 & 5.50 & 0.28 & 1.23 \\
\hline ALL & {$[9.89: 80.86]$} & 0.6 & 1.05 & 1.4 & 2.58 & 1.33 \\
\hline
\end{tabular}

Note: All calculations were made on the data from 01/01/2006 until 01/07/2013 on the basis of VIX futures with up to 7 months to expiration.

Table 10. Median 1-month VIX returns (in \%) conditional on VIX quintile groups and $V R P_{j, i}^{(a g g)}$ quartile groups

\begin{tabular}{|c|c|c|c|c|c|c|}
\hline $\begin{array}{c}\text { VIX } \\
\text { quintile }\end{array}$ & $V R P_{j . i}^{(a g g)}$ & $\begin{array}{c}\text { I } \\
\text { quartile } \\
\text { group }\end{array}$ & $\begin{array}{c}\text { II } \\
\text { quartile } \\
\text { group }\end{array}$ & $\begin{array}{l}\text { III } \\
\text { quartile } \\
\text { group }\end{array}$ & $\begin{array}{c}\text { IV } \\
\text { quartile } \\
\text { group }\end{array}$ & $\mathrm{A \amalg}$ \\
\hline group & VIX level & $\begin{array}{l}{[-2.19:} \\
-0.55]\end{array}$ & $\begin{array}{l}(-0.55: \\
-0.11]\end{array}$ & $\begin{array}{c}(-0.11: \\
0.58]\end{array}$ & $\begin{array}{c}\text { (0.58: } \\
3.68]\end{array}$ & $\begin{array}{c}{[-2.19:} \\
3.68]\end{array}$ \\
\hline 1 & [9.89:14.18] & 7.59 & 3.01 & -2.64 & 2.96 & 2.52 \\
\hline 2 & (14.18:17.74] & -7.72 & 0.06 & 12.13 & 2.17 & 5.36 \\
\hline 3 & $(17.74: 21.68]$ & -10.23 & 5.36 & -1.48 & -9.96 & -3.39 \\
\hline 4 & (21.68:26.85] & -5.87 & -12.34 & -5.21 & -7.42 & -7.62 \\
\hline 5 & $(26.85: 80.86]$ & -8.72 & -16.39 & -18.52 & -1168 & -12.06 \\
\hline ALL & {$[9.89: 80.86]$} & -5.13 & -0.59 & -0.56 & -4.63 & -2.68 \\
\hline
\end{tabular}

Note: All calculations were made on the data from 01/01/2006 until 01/07/2013 on the basis of VIX futures with up to 7 months to expiration. Red font denotes significantly negative returns while green font denotes significantly positive returns.

Table 11 and Table 12 do not add any new information. There is no any clear dependence between $V R P_{j, i}^{|a g g|}$ and S\&P500 return. The same conclu- 
sion we can drawn in the case of VIX returns and $V R P_{j, i}^{(a g g)}$ values (Table 12). The general conclusion concerning the part of the table with high positive and high negative VIX returns holds only in case of the negative returns.

Table 11. Median 1-month S\&P500 returns (in \%) conditional on VIX quintile groups and $V R P_{j, i}^{|a g g|}$ quartile groups

\begin{tabular}{|c|c|c|c|c|c|c|}
\hline $\begin{array}{c}\text { VIX } \\
\text { quintile }\end{array}$ & $V R P_{\mathrm{j} . \mathrm{i}}^{|\mathrm{agg}|}$ & $\begin{array}{c} \\
\text { quartile } \\
\text { group }\end{array}$ & $\begin{array}{c}\text { II } \\
\text { quartile } \\
\text { group }\end{array}$ & $\begin{array}{c}\text { III } \\
\text { quartile } \\
\text { group }\end{array}$ & $\begin{array}{l}\text { IV } \\
\text { quartile } \\
\text { group }\end{array}$ & ALL \\
\hline group & VIX level & [0.03: 0.33] & $\begin{array}{c}0.33: \\
0.58]\end{array}$ & $\begin{array}{c}0.58: \\
0.87]\end{array}$ & $\begin{array}{c}0.87: \\
3.68]\end{array}$ & $\begin{array}{l}0.03: \\
3.68]\end{array}$ \\
\hline 1 & [9.89:14.18] & 1.69 & 0.75 & 1.31 & 2.24 & 1.27 \\
\hline 2 & (14.18:17.74] & -2.28 & 0.87 & 1.63 & 2.16 & 0.86 \\
\hline 3 & (17.74:21.68] & 0.95 & -0.76 & 1.66 & 2.01 & 1.19 \\
\hline 4 & (21.68:26.85] & 2.74 & 1.12 & 2.22 & 3.83 & 2.48 \\
\hline 5 & (26.85:80.86] & 4.25 & 3.27 & 0.38 & 0.22 & 1.23 \\
\hline$\overline{A L L}$ & {$[9.89: 80.86]$} & 1.47 & 0.86 & 1.36 & 1.82 & 1.33 \\
\hline
\end{tabular}

Note: All calculations were made on the data from 01/01/2006 until 01/07/2013 on the basis of VIX futures with up to 7 months to expiration.

Table 12. Median 1-month VIX returns (in \%) conditional on VIX quintile groups and $V R P_{j, i}^{|a g g|}$ quartile groups

\begin{tabular}{|c|c|c|c|c|c|c|}
\hline $\begin{array}{c}\text { VIX } \\
\text { quintile }\end{array}$ & $V R P_{\mathrm{j} . \mathrm{i}}^{\text {|agg| }}$ & $\begin{array}{c}\text { I } \\
\text { quartile } \\
\text { group }\end{array}$ & $\begin{array}{c}\text { II } \\
\text { quartile } \\
\text { group }\end{array}$ & $\begin{array}{c}\text { III } \\
\text { quartile } \\
\text { group }\end{array}$ & $\begin{array}{l}\text { IV } \\
\text { quartile } \\
\text { group }\end{array}$ & ALL \\
\hline group & VIX level & $\begin{array}{l}{[0.03:} \\
0.33]\end{array}$ & $\begin{array}{l}0.33: \\
0.58] \\
\end{array}$ & $\begin{array}{l}0.58: \\
0.87] \\
\end{array}$ & $\begin{array}{l}0.87: \\
3.68]\end{array}$ & $\begin{array}{l}{[0.03:} \\
3.68]\end{array}$ \\
\hline 1 & [9.89:14.18] & -2.49 & 7.54 & 6.39 & -0.44 & 2.52 \\
\hline 2 & (14.18:17.74] & 13.68 & 5.89 & -3.32 & -0.57 & 5.36 \\
\hline 3 & (17.74:21.68] & 0.35 & 1.56 & -10.17 & -8.34 & -3.39 \\
\hline 4 & (21.68:26.85] & -13.8 & -3.5 & -3.67 & -9.24 & -7.62 \\
\hline 5 & (26.85:80.86] & -26.61 & -15.39 & -8.24 & -10.27 & -12.06 \\
\hline ALL & {$[9.89: 80.86]$} & -3.24 & 1.45 & -2.73 & -6.42 & -2.68 \\
\hline
\end{tabular}

Note: All calculations were made on the data from 01/01/2006 until 01/07/2013 on the basis of VIX futures with up to 7 months to expiration. Bold fonts denote values significantly different from zero.

Having found strong dependence patterns we will try to use them to design a simple investment strategy which is supposed to beat the market (S\&P500 buy\&hold strategy). 


\section{The Investment Model}

The main objective of this section is to design investment strategies which will implement the dependence of VIX and VIX futures returns on various $V T S$ and $V R P$ measures. This idea has been directly motivated by our previous study (Jabłecki et. al. 2013a), where we found evidence of significant relationship between lagged slope of VIX futures term structure and current level of VIX. This finding however, couldn't help us to get significantly lower average prediction errors of futures VIX level, when compared with naïve forecasts. We decided therefore to try to translate apparent connection between term structure of VIX futures and VIX level into a profitable investment strategy.

Our investment algorithms use the idea of mean reversion characteristics of VIX fluctuations and additionally, the information hidden in term structure of VIX futures shape and VRP values. Tables and figures presented earlier confirmed our initial intuition that VIX returns (and partly S\&P500 returns ${ }^{7}$ ) depend on the current level of VIX, VTS shape and VRP values. Higher slope of VTS (or high VRP value) together with lower VIX quintile group generally implicates high VIX returns, while lower slope of VTS (or low VRP value) together with higher VIX quintile group generally implicates very low VIX returns. Additionally, we observed that average S\&P500 index returns rise almost monotonically with the increase of both $V R P$ values and Slope2, revealing strong dependence between index future returns and the current level of risk perceived by market participants.

We propose five simple strategies which invests in VIX futures contracts. For comparison purposes we use S\&P500 buy\&hold strategy results.

The general assumptions for all strategies are as follows:

- transaction costs $=0.1 \%$,

- data gathering window: minimum one year,

- first signals: 2008-01-01, then the current closing price is used to generate a new signal for each consecutive day,

- trade price: closing price of VIX futures with nearest maturity,

- switch to the 2nd contract on the last trading day (rolling yields included),

- leverage: $100 \%$,

- margin: we do not receive any additional interests from cash above margin.

\footnotetext{
${ }^{7}$ We admit that dependence in case of S\&P500 returns is much weaker than in case of VIX returns.
}

DYNAMIC ECONOMETRIC MOdels 14 (2014) 5-28 
The detailed assumptions for each strategy and theirs results are presented below.

\subsection{Strategy I}

Positions are determined by following conditions:

- buy: if $V R P_{j}^{I}$ is in 1st quartile group,

- sell: if $V R P_{j}^{I}$ in 4th quartile group,

- close: if $V R P_{j}^{I}$ in 2nd quartile group after sell signal or in 3rd after buy signal,

- hold: if $V R P_{j}^{I}$ in 2 nd quartile group after buy signal or in $3^{\text {rd }}$ after sell signal.

Strategy I utilizes the assumption that VRP is mean reverting process and every departure from ,theoretical" volatility term structure should be reverted and should go back to zero. The problem is that while it is true inside VIX quintile groups, the logic of the signal can be weakened by switches between VIX quintile groups. This could be the reason of rather poor results of this strategy, which are presented in detail on Figure 7 and in Table 13 .

\subsection{Strategy II}

Positions are determined by following conditions:

- buy: if $V R P_{j}^{I}$ in 1st quartile group,

- sell: if $V R P_{j}^{I}$ in 4th quartile group,

- hold: if $V R P_{j}^{I}$ in 2nd or 3rd quartile group.

Strategy II is very similar to Strategy I but it has less strict rules concerning the moment when we close the position. The problem with switches between VIX quintile groups still exists but due to less frequent close signals the results of this strategy are most striking among all strategies (Figure 8 and Table 13).

\subsection{Strategy III}

Positions are determined by following conditions:

- buy: if $V R P_{j}^{I}$ in 1 st or 2nd quartile group,

- sell: if $V R P_{j}^{I}$ in $3 \mathrm{rd}$ or 4 th quartile group.

Strategy III is characterized by most frequent switches between short and long positions. Nevertheless, this modification does not enhance the results (Figure 9 and Table 13). 


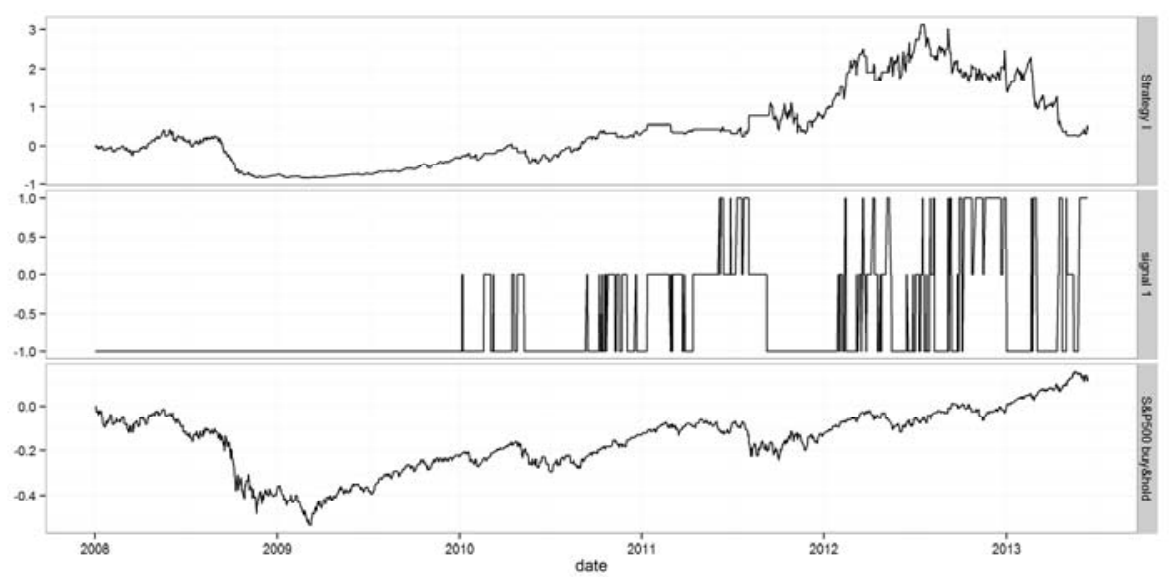

Figure 7. Equity line and signal of Strategy I for VIX futures and S\&P500 index. All calculations were made on the data from 01/01/2006 until 01/07/2013 on the basis of VIX futures with up to 7 months to expiration

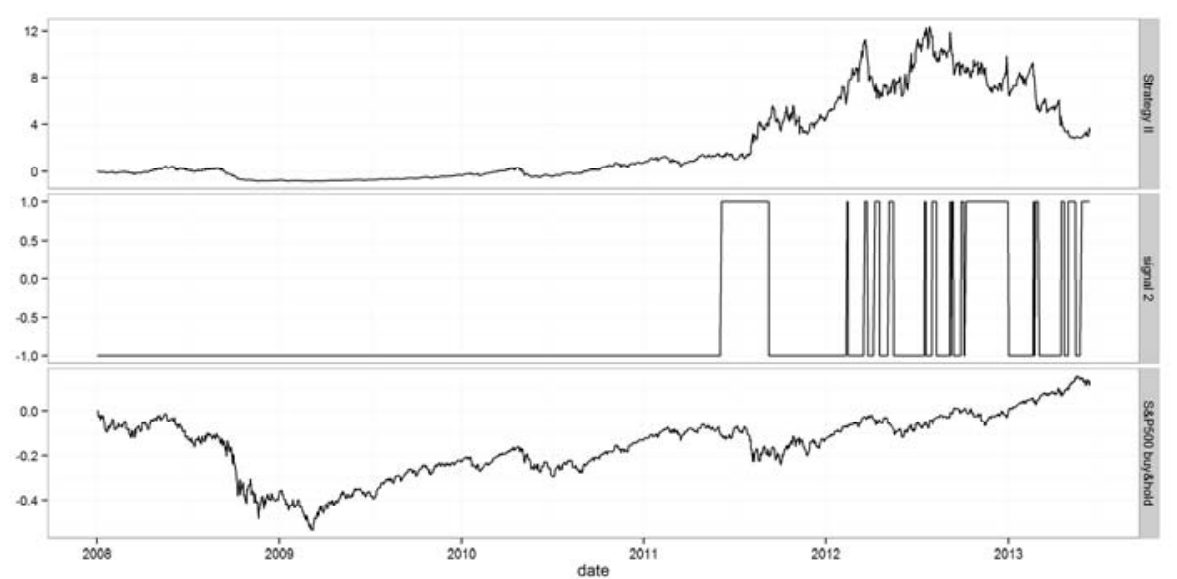

Figure 8. Equity line and signal of Strategy II for VIX futures and S\&P500 index. All calculations were made on the data from 01/01/2006 until 01/07/2013 on the basis of VIX futures with up to 7 months to expiration 


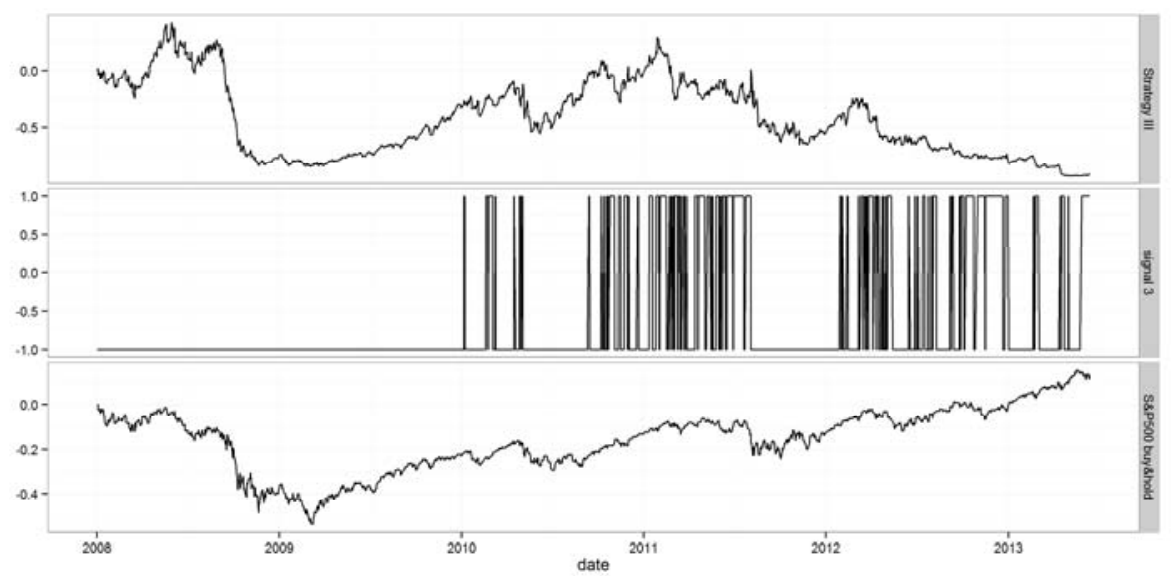

Figure 9. Equity line and signal of Strategy III for VIX futures and S\&P500 index. All calculations were made on the data from 01/01/2006 until 01/07/2013 on the basis of VIX futures with up to 7 months to expiration

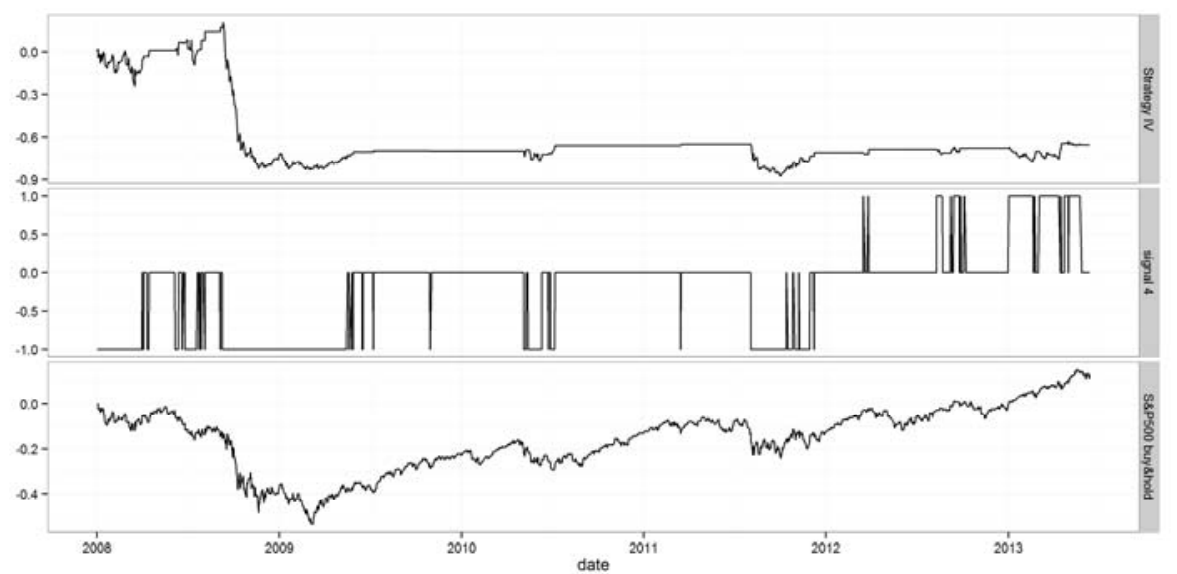

Figure 10. Equity line and signal of strategy IV for VIX futures and S\&P500 index. All calculations were made on the data from 01/01/2006 until 01/07/2013 on the basis of VIX futures with up to 7 months to expiration

\subsection{Strategy IV}

Positions are determined by following conditions:

- buy: if VIX in 1st or 2nd quintile group, 
- sell: if VIX in 4th or 5th quintile group,

- hold: otherwise.

Strategy IV signals depend only on VIX level. It uses extreme quintiles of VIX in order to generate buy and sell signals for VIX futures. The position is hold until the opposite signal is generated. The results of this approach are rather poor (Figure 10 and Table 13).

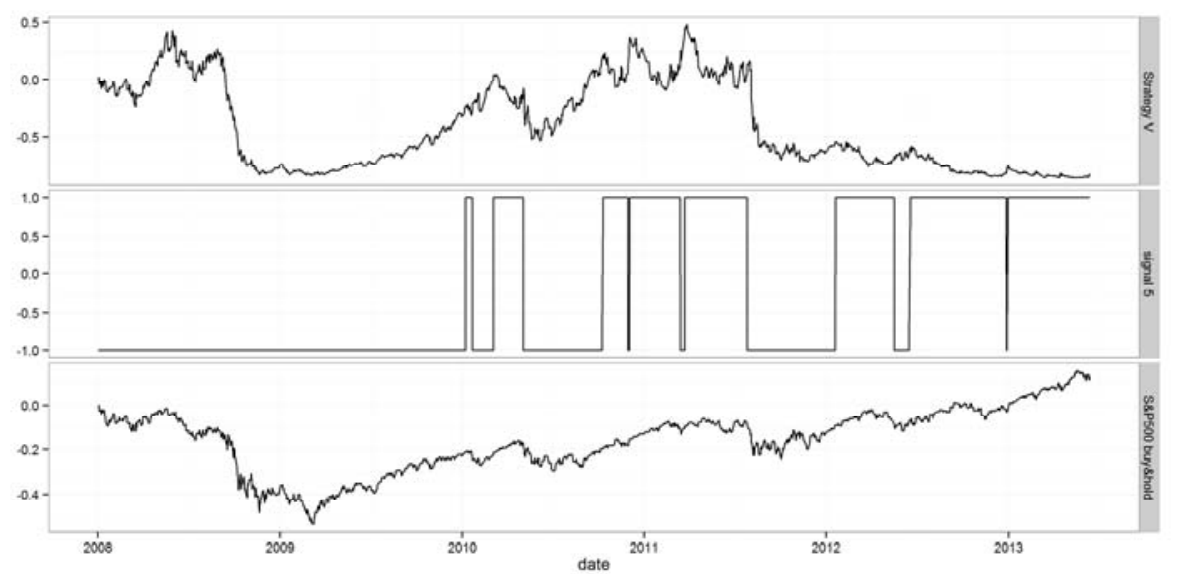

Figure 11. Equity line and signal of strategy V for VIX futures and S\&P500 index. All calculations were made on the data from 01/01/2006 until 01/07/2013 on the basis of VIX futures with up to 7 months to expiration

\subsection{Strategy $V$}

Positions are determined by following conditions:

- buy: if VIX in 1st or 2nd quintile group,

- sell: if VIX in 4th or 5th quintile group,

- close: otherwise.

Strategy V uses the same logic as Strategy IV but closes its positions more often what in fact is once again not the best option (Figure 11 and Table 13).

\subsection{Comparison of All Strategies}

Results are summarized in Table 13. To compare the strategies under consideration, we use several popular risk-return measures.

After detailed analysis of presented results we can notice that only Strategy II can beat the market represented by S\&P500 buy\&hold (Strategy VI). Return (ARC) and return-risk statistics (information ratio, Sharpe and Treynor coefficients) are much better for this strategy. On the other hand, risk 
statistics show that strategy II is characterized by relatively high beta coefficient, and what is more, by much higher level of standard deviation (ASD) and maximum drawdown (MaxD) when compared with the benchmark strategy.

Table 13. Return and risk statistics for all investment strategies

\begin{tabular}{ccccccc}
\hline & $\begin{array}{c}\text { Strategy } \\
\text { I }\end{array}$ & $\begin{array}{c}\text { Strategy } \\
\text { II }\end{array}$ & $\begin{array}{c}\text { Strategy } \\
\text { III }\end{array}$ & $\begin{array}{c}\text { Strategy } \\
\text { IV }\end{array}$ & $\begin{array}{c}\text { Strategy } \\
\text { V }\end{array}$ & $\begin{array}{c}\text { Strategy } \\
\text { VI } \\
\text { buy\&hold }\end{array}$ \\
\hline ARC (\%) & 6.56 & 30.81 & -36.84 & -17.80 & -29.24 & 2.28 \\
ASD (\%) & 71.48 & 81.02 & 81.17 & 54.97 & 81.09 & 25.43 \\
IR & 0.09 & 0.38 & -0.45 & -0.32 & -0.36 & 0.09 \\
Sharpe & 0.08 & 0.37 & -0.46 & -0.34 & -0.37 & 0.06 \\
Treynor & 0.03 & 0.18 & -0.21 & -0.14 & -0.20 & 0.02 \\
Beta & 1.67 & 1.67 & 1.80 & 1.32 & 1.47 & 1.00 \\
MaxD (\%) & -69.58 & -71.57 & -95.04 & -89.55 & -90.82 & -53.25 \\
\hline
\end{tabular}

Note: All calculations were made on the data from 01/01/2006 until 01/07/2013 on the basis of VIX futures with up to 7 months to expiration. ARC - annualized return compounded, ASD, annualized standard deviation, IR - information ratio, Sharpe - Sharpe ration, Treynor - Treynor ratio, Beta - slope of regression of a given strategy on buy\&hold strategy, MaxD - maximum drawdown.

\section{Conclusions}

Based on the presented results we can conclude that:

1. Volatility time structure (VTS) shape and volatility risk premium (VRP) values are important in order to predict VIX and partly S\&P500 index futures.

2. We observe very high positive VIX returns for the first and the second VIX quintile groups and for the fourth and the fifth Slope1 (Slope2, $V R P_{j}^{I}, V R P_{j, i}^{(a g g)}, V R P_{j, i}^{|a g g|}$ ) quintile groups. On the other hand, we observe very high negative VIX returns for the fourth and the fifth VIX quintile groups.

3. It is possible to use information from term structure of VIX futures to construct profitable strategies (Strategy II) which enhance our returnrisk ratio when compared with S\&P500 buy\&hold Strategy VI.

It seems that it would be important to extend these conclusions of this research on other volatility and equity index futures (e.g. VSTOXX and EuroStoxx50, VNKY and Nikkei 225 and other volatility futures quoted on $\mathrm{CBOE} / \mathrm{CFE}$ ). Additionally, we would like to test investment strategies where each characteristics will be calculated on rolling two years window instead of anchored window used in this study. Further research on various definition of volatility term structure are even more important because more ade- 
quate reference to so called "normal" or equilibrium level of VTS is the crucial point in defining diverse volatility arbitrage strategies.

\section{References}

Alexander, C., Korovilas D. (2011), The Hazards of Volatility Diversification, ICMA Centre Discussion Papers in Finance DP2011-04, ICMA, DOI: http://dx.doi.org/10.2139/ssrn.1752389.

Andersen, T. G., Bollerslev, T., Christoffersen, P. F., Diebold, F. X. (2005), Volatility Forecasting, NBER Working Paper 11188, DOI: http://dx.doi.org/10.2139/ssrn.673405.

Asensio, I. O. (2013), The VIX-VIX Futures Puzzle, mimeo.

Bakshi, G., Kapadia, N. (2003), Delta-hedged Gains and the Negative Market Volatility Risk Premium, Review of Financial Studies, 16(2), 527-566.

Black, F., Scholes, M. (1973), The Pricing of Options and Corporate Liabilities, Journal of Political Economy, 81(3), 637-54, DOI: http://dx.doi.org/10.1086/260062.

Bollen, N. P. B., Whaley, R. E. (2004), Does Net Buying Pressure Affect the Shape of Implied Volatility Functions?, Journal of Finance, 59(2), 711-753. DOI: http://dx.doi.org/10.2139/ssrn.319261.

Bondarenko, O. (2004), Market Price of Variance Risk and Performance of Hedge Funds, University of Illinois Chicago working paper.

Bossu, S. (2006), Introduction to Variance Swaps, Wilmott Magazine, 50-55.

Brenner, M., Galai, D. (1989), New Financial Instruments for Hedging Changes in Volatility, Financial Analysts Journal, 45(4), 61-65, DOI: http://dx.doi.org/10.2469/faj.v45.n4.61.

Briere, M., Fermanian, J.-D., Malongo, H., Signori, O. (2011), Volatility Strategies for Global and Country Specific European Investors, DOI: http://dx.doi.org/10.2139/ssrn.1945703.

Carr, P., Lee, R. (2007), Realised Volatility and Variance: Options via Swaps, Risk, 20, 76-83.

Carr, P., Lee, R. (2009), Volatility Derivatives, Annual Review of Financial Economics, 1(1), 319-339, DOI: http://dx.doi.org/10.1146/annurev.financial.050808.114304.

Carr, P., Lewis, K. (2004), Corridor Variance Swaps, Risk, 17, 67-72.

Carr, P., Madan, D. (2001), Towards a Theory of Volatility Trading, [in:] Jarrow, R. (ed.), Volatility. New Estimation Techniques for Pricing Derivatives, in Jouini, E., Cvitanic, J., Musiela, M. (ed.), Option Pricing, Interest Rates and Risk Management, Cambridge University Press, Cambridge, 458-476.

Carr, P., Wu, L. (2009), Variance risk premiums, Review of Financial Studies, 22(3), 1311-1341, DOI: http://dx.doi.org/10.1093/rfs/hhn038.

CBOE (2003), The CBOE Volatility Index - VIX, http://www.cboe.com/micro/vix/vixwhite.pdf.

CBOE (2009), The CBOE Volatility Index - VIX, Chicago Board Options Exchange.

Chen, K., He, X., Poon, S.-H. (2010), The Art of Volatility Modelling. A Case Study Based on DBS, mimeo.

Cox, J. C., Rubinstein, M. (1985), Options Markets. Prentice Hall.

Daigler, R. T., Rossi, L. (2006), A portfolio of stocks and volatility, The Journal of Investing, 15(2), 99-106, DOI: http://dx.doi.org/10.3905/joi.2006.635636.

Dash, S., Moran, M. T. (2005), VIX as a Companion for Hedge Fund Portfolios, The Journal of Alternative Investments, 8(3), 75-80, 
DOI: http://dx.doi.org/10.3905/jai.2005.608034.

Demeterfi, K., Derman, E., Kamal, M., Zou, J. (1999), A Guide to Volatility and Variance Swaps, The Journal of Derivatives, 6(4), 9-32, DOI: http://dx.doi.org/10.3905/jod.1999.319129.

Derman, E., Demeterfi, K., Kamal, M., Zou, J. (1999), More Than You Ever Wanted To Know About Volatility Swaps, Quantitative strategies research notes, Goldman Sachs.

Derman, E., Kamal, M., Kani, I., McClure, J., Pirasteh, C., Zou, J. Z. (1998), Investing in Volatility, [in:] Futures and Options World, Special Supplement on the 25th Anniversary of the Publication of the Black-Scholes Model.

Derman, E., Taleb, N. N. (2005), The Illusions of Dynamic Replication, Quantitative Finance, 5(4), 323-326, DOI: http://dx.doi.org/10.1080/14697680500305105.

Dupire, B. (1993), Model Art, Risk, 6, 118-120.

Dupire, B. (2004), A Unified Theory of Volatility, Working paper, Paribas Capital Markets.

Egloff, D., Leippold, M., Wu, L. (2010), The Term Structure of Variance Swap Rates and Optimal Variance Swap Investments, Journal of Financial and Quantitative Analysis, 45(5), DOI: http://dx.doi.org/10.1017/S0022109010000463.

Fassas, A. P. (2012), The Relationship Between VIX Futures Term Structure and S\&P500 Returns, Review of Futures Markets, 20, 293-313.

Fleming, J., Ostdiek, B., Whaley, R. E. (1995), Predicting Stock Market Volatility: A new measure, Journal of Futures Markets, 15(3), 265-302.

Galai, D. (1979), A Proposal for Indexes for Traded Call Options, The Journal of Finance, 34(5), 1157-1172, DOI: http://dx.doi.org/10.2307/2327241.

Gastineau, G. L. (1977), An Index of Listed Option Premiums, Financial Analysts Journal, 33(3), 70-75, DOI: http://dx.doi.org/10.2469/faj.v33.n3.70.

Giot, P. (2005), Relationship between Implied Volatility Index and Stock Index Returns, Journal of Portfolio Management, 31, 92-100.

Guobuzaite, R., Martellini, L. (2012), The Benefits of Volatility Derivatives in Equity Portfolio Management, EDHEC - Risk Institute.

Hafner, R., Wallmeier, M. (2008), Optimal Investments in Volatility, Financial Markets and Portfolio Management, 22(2), 147-167, DOI: http://dx.doi.org/10.1007/s11408-008-0076-8.

Herrmann, R., Luedecke, T. (2002), Why the VOLAX Future Has Failed, [in:] 9thSymposium on Finance, Banking, and Insurance, Universitaet Karlsruhe (TH), Germany.

Huskaj, B., Nossman, M. (2012), A Term Structure Model for VIX Futures, Journal of Futures Markets, 33(5), 421-442, DOI: http://dx.doi.org/10.1002/fut.21550.

Jabłecki, J., Kokoszczyński, R., Sakowski, P., Ślepaczuk, R., Wójcik, P. (2012), Pomiar i modelowanie zmienności - przegląd literatury, Ekonomia, 31, 22-55.

Jabłecki, J., Kokoszczyński, R., Sakowski, P., Ślepaczuk, R., Wójcik, P. (2013a), Struktura czasowa zmienności kontraktów terminowych na VIX - modelowanie i własności prognostyczne, Zarzadzanie i Finanse, 11(2), 181-192.

Jabłecki, J., Kokoszczyński, R., Sakowski, P., Ślepaczuk, R., Wójcik, P. (2013b), Instrumenty pochodne na zmienność - nowa klasa aktywów?, WNE UW.

Kitces, M. E. (2012), What Makes Something an Alternative Asset Class, Anyway?, Journal of Financial Planning, 22-23.

Kolanovic, M. (2012), The VIX: Rewards and Risks of a Rapidly Growing Market, Discussion paper, Columbia University Financial Engineering Practitioners Seminar, $\mathrm{http} / / /$ ieor.columbia.edu/financial-engineering-practitioners-seminar.

Konstantinidi, E., Skiadopoulos, G. (2011), Are VIX Futures Prices Predictable? An Empirical Investigation, International Journal of Forecasting, 27, 543-560, 
DOI: http://dx.doi.org/10.1016/j.ijforecast.2009.11.004.

Merton, R. C. (1973), Theory of Rational Option Pricing, Bell Journal of Economics, 4(1), 141-183, DOI: http://dx.doi.org/10.2307/3003143.

Moran, M. T., Dash, S. (2007), VIX Futures and Options: Pricing and Using Volatility Products to Manage Downside Risk and Improve Efficiency in Equity Portfolios, The Journal of Trading, 2(3), 96-105, DOI: http://dx.doi.org/10.3905/jot.2007.688954.

Neuberger, A. (1994), The Log Contract, The Journal of Portfolio Management, 20(2), 74 -80, DOI: http://dx.doi.org/10.3905/ipm.1994.409478.

Nieto, B., Novales, A., Rubio, G. (2012), Variance Swaps, Non-normality and Macroeconomic and Financial Risks, The Quarterly Review of Economics and Finance, 54(2), 257 -270, DOI: http://dx.doi.org/10.1016/j.qref.2013.12.002.

Signori, O., Briere, M., Burgues, A. (2010), Volatility Exposure for Strategic Asset Allocation, Journal of Portfolio Management, 36(3), 105-116, DOI: http://dx.doi.org/10.3905/jpm.2010.36.3.105.

Simon, D., Wiggins, R. (2001), S\&P Futures Returns and Contrary Sentiment Indicators, Journal of Futures Markets, 21, 447-462, DOI: http://dx.doi.org/10.1002/fut.4.

Szado, E. (2009), VIX Futures and Options: A Case Study of Portfolio Diversification during the 2008 Financial Crisis, The Journal of Alternative Investments, 12(2), 68-85.

Whaley, R. E. (1993), Derivatives on Market Volatility: Hedging Tools Long Overdue, Journal of Derivatives, 1, 71-84, DOI: http://dx.doi.org/10.3905/jod.1993.407868.

Yamai, Y., Yoshiba, T. (2005), Value-at-risk versus Expected Shortfall: A Practical Perspective, Journal of Banking \& Finance, 29(4), 997-1015,

DOI: http://dx.doi.org/10.1016/j.jbankfin.2004.08.010.

\section{Czy struktura terminowa zmienności zawiera istotne informacje w celu prognozowania zachowania się kontraktów terminowych na zmienność i indeksy giełdowe?}

Z a r y s t r e ś c i. Badanie pozwoliło nam stwierdzić, że struktura terminowa kontraktów na zmienność (indeks VIX), a konkretniej jej nachylenie, jest zależna od aktualnego poziomu indeksu VIX. W momencie, w którym indeks VIX jest na niskim poziomie (poniżej 20) struktura terminowa ma wysokie dodatnie nachylenie, natomiast $\mathrm{w}$ momencie, w którym indeks VIX jest na wysokim poziomie (powyżej 30) to wtedy struktura ma ujemne nachylenie. Wykorzystujemy te obserwacje, aby lepiej przewidywać zachowanie się stóp zwrotu kontraktów terminowych na zmienność. Na początek wprowadzamy miary ilościowe struktury terminowej zmienności $(V T S)$ oraz premii za ryzyko zmienności $(V R P)$. VRP pozwala nam określić stopień odchylenia obecnej struktury terminowej od tzw. modelowej dla danego poziomu indeksu VIX. Zauważamy, że wielkość odchylenia ma istotne własności predykcyjne i dlatego w końcowej części artykułu proponujemy strategie inwestycyjne wykorzystujące tę koncepcję przy budowie algorytmów inwestycyjnych generujących sygnały na rynku kontraktów terminowych na indeks VIX.

S łow a kluc zowe: struktura terminowa zmienności, premia za ryzyko zmienności, kontrakty terminowe na zmienność i indeksy giełdowe, zmienność zrealizowana, zmienność implikowana, strategia inwestycyjna, prognozowanie stóp zwrotu, efektywne miary ryzyka i stóp zwrotu 